\title{
STATUS GANDA \\ LEMBAGA INTERMEDIASI KEUANGAN PERBANKAN SYARIAH DALAM MENJALANKAN AKAD MUDHARABAH
}

\author{
Wasman dan Asep Hilman Nuryaman \\ Fakultas Syariah dan Ekonomi Islam \\ Institut Agama Islam Negeri Syekh Nurjati Cirebon \\ email:wasman1959@yahoo.co.id dan aseph8276@gmail.com
}

\begin{abstract}
Mudharabah is the most important contract muamalah underlying Islamic banking products. However, implementation as one of the mudharabah contract in Islamic banking products has attracted criticism. This criticism appears, because in the scheme of mudharabah run Islamic banking violate the provisions described in the economic law of sharia, one of which is their dual status of Islamic banking (bank acts as shahibul maal and mudharib) when running the scheme mudharabah in the product collection and disbursement of funds. The results showed that the misalignment between the intermediary function of the characteristics of mudharabah resulted mudharabah who do become damaged, it can be seen from their dual status and the absence of real business in Islamic banking should be in mudharabah, in addition to their dual status in banking sharia in mudharabah it self makes laws mudharabah run islamic banking needs to be questioned.
\end{abstract}

Keywords: Dual Status and Islamic Banking.

\begin{abstract}
Abstrak
Mudharabah merupakan akad muamalah paling utama yang melandasi produk perbankan syariah. Namun implementasi mudharabah sebagai salah satu akad dalam produk di perbankan syariah telah menuai kritik. Kritik ini muncul, karena dalam skema akad mudharabah yang dijalankan perbankan syariah menyalahi ketentuan-ketentuan yang dijelaskan dalam hukum ekonomi syariah, salah satunya adalah adanya status ganda perbankan syariah (bank berperan sebagai shahibul maal dan mudharib) ketika menjalankan skema akad mudharabah dalam produk penghimpunan dan penyaluran dana. Hasil penelitian menunjukan bahwa ketidakselarasan antara fungsi intermediasi dengan karakteristik akad mudharabah mengakibatkan akad mudharabah yang dilakukan menjadi rusak, hal ini bisa dilihat dari adanya status ganda dan tidak adanya usaha riil di perbankan syariah yang seharusnya ada dalam akad mudharabah, selain itu adanya status ganda di perbankan syariah dalam akad mudharabah itu sendiri membuat hukum mudharabah yang dijalankan perbankan syariah perlu dipertanyakan.
\end{abstract}

Kata Kunci: Status Ganda dan Perbankan Syariah. 


\section{PENDAHULUAN}

Lembaga Keuangan menurut SK Menkeu RI No. 792 Tahun 1990 adalah suatu badan yang kegiatannya di bidang keuangan, melakukan penghimpunan dan penyaluran dana kepada masyarakat terutama guna membiayai investasi perusahaan. ${ }^{1}$

Salah satu lembaga keuangan ialah Bank. Menurut Undang-Undang No.10 tahun 1998 tentang Perbankan, dalam pasal 1 ayat 2 disebutkan bahwa Bank adalah badan usaha yang menghimpun dana dari masyarakat dalam bentuk simpanan dan menyalurkannya kepada masyarakat dalam bentuk kredit dan atau bentuk-bentuk lainnya dalam rangka meningkatkan taraf hidup rakyat banyak. ${ }^{2}$ Dari pengertian di atas dapat disimpulkan peran bank sebagai lembaga perantara keuangan antara pihakpihak yang memiliki kelebihan dana dengan pihak-pihak yang memerlukan dana.

Pesatnya laju perekonomian yang banyak bergantung dengan aktifitas perbankan. Maka para konseptor perbankan syariah (islamic bank) di Indonesia berupaya melakukan penyelarasan sistem perbankan agar bersesuaian dengan hukum Islam.

Sistem yang digunakan dalam bank konvensional telah terbukti secara nyata tidak mengindahkan berbagai larangan dalam ketentuan syariah Islam, contohnya dalam layanan meminjamkan uang atau memungut pinjaman dengan mengenakan bunga pinjaman (riba), padahal telah diketahui bersama berdasar kesepakatan para ahli ilmu agama (ahli fiqh) bahwa dalam akad muamalah pinjam meminjam didalam ketentuan syariat Islam tidak dibolehkan didalamnya dimasukan unsur komersil atau pengambilan keuntungan, hal ini disebabkan bahwa keuntungan dari transaksi pinjam meminjam adalah riba. Oleh karena itu, para ulama menyusun

\footnotetext{
${ }^{1}$ Y. Sri Susilo at all, Bank dan Lembaga Keuangan Lain (Jakarta: Salemba Empat, 2000), 2-3.

${ }^{2}$ Lihat pasal 1 ayat 2 Undang-Undang Nomor 10 Tahun 1998 tentang Perbankan yang dipublikasikan oleh www.sjdih.depkeu.go.id. Diakses pada 10 Desember 2016.
}

sebuah kaidah penting untuk mengetahui aplikasi riba dalam berbagai jenis akad yaitu:

$$
\text { كل قرض جر نفعا فهو ربا }
$$

Artinya: Setiap pinjaman yang memberikan manfaatan adalah riba. ${ }^{3}$

Seiring waktu berjalan, saat terjadinya interaksi diantara praktisi perbankan, pengguna perbankan (nasabah) dengan para ahli ilmu (para ulama) serta dengan kajiankajian yang mendalam maka sedikit demi sedikit mulai bermunculan temuan nyata berbagai penyimpangan yang terjadi di perbankan syariah baik dalam produk penghimpun maupun produk pembiayaannya.

Menurut Undang-Undang No. 21 Tahun 2008 tentang Perbankan Syariah, bank syariah yang terdiri dari Bank Umum Syariah dan Bank Pembiayaan Rakyat Syariah (Pasal 18) serta Unit Usaha Syariah, pada dasarnya melakukan kegiatan usaha yang sama dengan bank konvensional, yaitu melakukan penghimpunan dan penyaluran dana masyarakat disamping penyediaan jasa keuangan lainnya. ${ }^{4}$

Undang-Undang di atas menjelaskan bahwa fungsi bank syariah sama dengan bank konvensional yakni fungsi intermediasi, dimana bank menghimpun dana dari masyarakat lalu disalurkan kepada pihak yang membutuhkan pembiayaan.

Hal ini menjadi bermasalah ketika fungsi intermediasi ini digabungkan dengan akad mudharabah yang secara konsep saling bertolak belakang, dimana dalam akad mudharabah memerlukan usaha riil sedangkan dalam fungsi intermediasi (perantara) tidak perlu adanaya usaha riil, selain itu saling bertolak belakangnya konsep intermediasi dan akad mudharabah membuat perbankan syariah memiliki status
${ }^{3}$ Erwandi Tarmizi, Harta Haram Muamalat Kontemporer (Bogor: PT. Berkat Mulia Insani, 2014), 351-352.

4 Iktisar Undang-Undang Nomor 21 tahun 2008 tentang Perbankan Syariah yang dipublikasi oleh www.bi.go.id. Diakses pada 12 Desember 2016. 
ganda dalam menjalankan akad mudharabah, dimana perbankan syariah bertindak sebagai mudharib (pengelola usaha) ketika berhadapan dengan nasabah (investor), disisi lain perbankan syariah juga bertindak sebagai shahibul mal (pemilik modal) ketika berhadapan dengan nasabah (yang kekurangan dana).

Oleh karena itu dengan adanya latar belakang tersebut, maka penulis tertarik untuk rumusan masalah dalam penelitian ini, yaitu pertama, bagaimana peran perbankan syariah sebagai lembaga intermediasi keuangan terhadap keabsahan akad mudharabah? Dan kedua, bagaimana status ganda perbankan syariah dalam akad mudharabah menurut hukum ekonomi syariah beserta dampaknya?

\section{LANDASAN TEORI}

\section{Perbankan Syariah sebagai Lembaga Intermediasi Keuangan}

Intermediasi secara bahasa adalah perantara/penghubung. ${ }^{5}$ Intermediasi keuangan merupakan proses penyerapan dana dari unit surplus ekonomi, baik sektor usaha, lembaga pemerintah maupun individu (rumah tangga) untuk penyediaan dana bagi unit ekonomi lain. ${ }^{6}$

Jadi, intermediasi keuangan adalah kegiatan pengalihan/penyaluran dana dari penabung (kelebihan dana) kepada peminjam (kekurangan dana), yang dilakukan oleh lembaga keuangan sebagai mediator.

Lembaga keuangan menurut SK Menkeu RI No. 792 Tahun 1990 adalah suatu badan yang kegiatannya di bidang keuangan, melakukan penghimpunan dan penyaluran dana kepada masyarakat terutama guna membiayai investasi perusahaan. ${ }^{7}$ Secara umum dapat disimpulkan bahwa lembaga keuangan

\footnotetext{
${ }^{5}$ KBBI IV (Kamus Besar Bahasa Indonesia) Online diakses dari http://kamus123.com. Diakses pada 09 Februari 2017.

${ }^{6}$ Andri Soemitra, Bank dan Lembaga Keuangan Syariah (Jakarta: Kencana, 2009), 29.

${ }^{7}$ Y. Sri Susilo at all., Bank dan Lembaga Keuangan Lain, 2-3.
}

berperan sebagai lembaga intermediasi keuangan.

Pengertian bank dalam UndangUndang Nomor 21 Tahun 2008 tentang Perbankan Syariah yakni Bank adalah badan usaha yang menghimpun dana dari masyarakat dalam bentuk simpanan dan menyalurkannya kepada masyarakat dalam bentuk kredit dan atau bentuk-bentuk lainnya dalam rangka meningkatkan taraf hidup rakyat banyak. ${ }^{8}$

Pengertian di atas merupakan pengertian umum yang menggambarkan fungsi bank secara pokok sebagai pengumpul dan penyalur dana. Maka dapat disimpulkan bahwa bank merupakan suatu lembaga yang berfungsi sebagai perantara (intermediasi) antara pihak yang kelebihan dana dan pihak yang membutuhkan dana, memperlancar arus pembayaran dimana aktivitasnya bertujuan untuk meningkatkan taraf kehidupan rakyat.

Jika dicermati, maka kegiatan bank umum baik bank umum konvensional maupun bank umum syariah pada hakikatnya sama, tidak terkecuali dengan fungsi intermediasi ini, dimana fungsi intermediasi (perantara) ini juga merupakan fungsi inti yang melekat pada perbankan syariah. Hal ini tercermin pada isi UndangUndang No. 21 tahun 2008 tentang Perbankan Syariah, bank syariah yang terdiri dari Bank Umum Syariah dan Bank Pembiayaan Rakyat Syariah (Pasal 18) serta Unit Usaha Syariah, pada dasarnya melakukan kegiatan usaha yang sama dengan bank konvensional, yaitu melakukan penghimpunan dan penyaluran dana masyarakat disamping penyediaan jasa keuangan lainnya. ${ }^{9}$

Hal ini diperjelas dalam UndangUndang No. 21 Tahun 2008 tentang Perbankan Syariah yang menyatakan bahwa

\footnotetext{
${ }^{8}$ Pasal 1 ayat 2 Undang-Undang Nomor 21 Tahun 2008 tentang Perbankan Syariah yang dipublikasikan oleh www.ojk.go.id. Diakses pada 10 Desember 2016.

${ }^{9}$ Iktisar Undang-Undang No. 21 tahun 2008 tentang Perbankan Syariah yang dipublikasi oleh www.bi.go.id. Diakses pada 12 Desember 2016.
} 
Bank Syariah dan UUS wajib menjalankan fungsi menghimpun dan menyalurkan dana masyarakat. ${ }^{10}$

\section{Akad Mudharabah}

Mudharabah disebut juga Qirad. ${ }^{11}$ Makna keduanya sama, dalam bahasa irak (penduduk irak) menamakannya mudharabah, sedangkan penduduk hijaz menyebutnya qiradh. $^{12}$ Pengertian Mudharabah juga dikemukakan oleh Ibnu Qudamah dalam Al-Mughni:

Artinya: Penduduk Iraq menggunakan istilah mudharabah untuk menyebut transaksi syarikah ini. Disebut sebagai mudharabah, karena diambil dari kata dharb di muka bumi. Yang artinya, melakukan perjalanan yang umumnya untuk berniaga dan berperang. Allah berfirman. Artinya: "(Dia mengetahui bahwa akan ada di antara kamu) orang-orang yang berjalan di muka bumi mencari sebagian karunia Allah" AlMuzzammil : 20 Ada juga yang mengatakan diambil dari kata dharb (mengambil) keuntungan dengan saham yang dimiliki. Dalam istilah bahasa Hijaz, disebut juga dengan qiradh. ${ }^{13}$

Sedangkam menurut istilah fiqih, mudharabah adalah ;

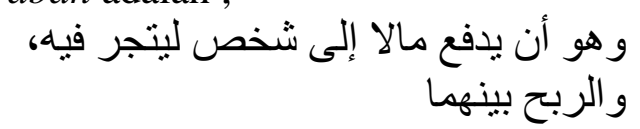

Artinya: (Mudharabah) yakni memberikan harta kepada seseorang

\footnotetext{
${ }^{10}$ Pasal 4 ayat 1 Undang-Undang No. 21 Tahun 2008 tentang Perbankan Syariah Lihat Prides dan Tim Manajemen, Kompilasi Perundang-undangan tentang Ekonomi Syariah (Jakarta: Gaung Persada Press, 2008), 8.

${ }^{11} \mathrm{Abu}$ Zakaria An Nawawi, Raudhatut Thalibin Wa Umdatul Muftin, Jilid 5 (Beirut: Al Maktab Al Islami, 1991), 117.

${ }^{12}$ Lihat Rachmat Syafei, Fiqih Muamalah (Bandung : Pustaka Setia, 2001), 223.

${ }^{13}$ Ibnu Qudamah, Al Mughni, jilid 7 (Riyadh: Dar 'Alamul Kutub, 1997), 133.
}

\section{untuk diniagakan dan keuntungan dibagi antara mereka. ${ }^{14}$}

Prinsip mudharabah terbagi menjadi dua yaitu mudharabah mutlaqah (investasi tidak terikat) dan mudharabah muqayyadah (investasi terikat). ${ }^{15}$

Dalam mudharabah, salah satu pihak berfungsi sebagai shahibul maal (pemilik modal) dan pihak yang lain berperan sebgai mudharib (pengelola) dengan nisbah bagi hasil menurut kesepakatan di muka. Mudharib merupakan orang yang diberi amanah dan juga sebagai agen usaha. Sebagai orang yang diberi amanah, ia dituntut untuk bertindak hati-hati dan bertanggung jawab terhadap kerugian yang terjadi karena kelalaiannya. Sebagai agen usaha, ia diharapkan mempergunakan dan mengelola modal sedemikian rupa untuk menghasilkan laba optimal bagi usaha yang dijalankan tanpa melanggar nilai-nilai syariah islam. ${ }^{16}$

\section{Rukun dan Syarat Mudharabah}

Imam An-Nawawi dalam Rhaudhatut Thalibin menyebutkan bahwa Mudharabah رأس المال (1) Modal, 2) العمل Kerja / Jenis usaha (Pekerjaan), 3) الربح Keuntungan (Laba), 4) الصيغة Pelafalan Transaksi / Ijab Qabul, dan 5) Dua Pelaku Transaksi. ${ }^{18}$

\footnotetext{
${ }^{14}$ Abu Zakaria An Nawawi, Raudhatut Thalibin Wa Umdatul Muftin, Jilid 5 (Beirut:Al Maktab Al Islami, 1991), 117.

${ }^{15}$ Sofyan Syafri Harahap, dkk., Akutansi Perbankan Syariah (Jakarta: LPFE Usakti, 2005), 67.

${ }^{16}$ Adrian Sutedi, Perbankan Syariah Tinjauan dan Beberapa Segi Hukum (Bogor: Ghalia Indonesia, 2009), 70.

${ }^{17}$ Selengkapnya lihat Abu Zakaria An Nawawi, Raudhatut Thalibin Wa Umdatul Muftin, Jilid 5 (Beirut:Al Maktab Al Islami, 1991), 117-124.

18 وَهُمَا رَبُّ الْمَالِ وَالْمُضَتَارِبُ yaitu pemilik modal dan pengelola Usaha/Pengusaha, Lihat Al Kasany Al Hanafy, Badaa'i Ash Shanaa'i Fi Tartib Asy Syara'i, Jilid 6 (Beirut: Darul Kutub Al Ilmiyah, 1986), 81. Lihat juga Isriani Hardini dan Muh. Giharto, Kamus Perbankan Syariah: Dilengkapi Penjelasan Singkat dan Perbandingan dengan Bank Konvensional (Bandung: Marja, 2007), 52 \& 65.
} 
Adapun Syarat-syarat yang terdapat dalam akad Mudharabah adalah sebagai berikut:

Pertama, penyedia dana (sahibul maal) dan pengelola (mudharib) harus cakap hukum.

$$
\text { الماللك أهلية الأول العاقدان ولهما شروط والعامل أهلية التوكل }
$$

Artinya: Dan rukun pertama adalah dua orang yang berakad dan mempunyai syarat yakni pemilik modal dan pengelola usaha harus cakap. $^{19}$

Kedua, pernyataan ijab dan qabul harus dinyatakan oleh para pihak untuk menunjukkan kehendak mereka dalam mengadakan kontrak (akad), ${ }^{20}$ dengan memperhatikan hal-hal berikut; 1) Penawaran dan penerimaan harus secara eksplisit menunjukkan tujuan kontrak (akad). 2) Penerimaan dari penawaran dilakukan pada saat kontrak. Dan ketiga, akad dituangkan secara tertulis, melalui korespondensi atau dengan menggunakan cara-cara komunikasi modern.

Dan ketiga, modal ialah sejumlah uang dan/atau aset yang diberikan oleh penyedia dana kepada pengelola (mudharib) untuk tujuan usaha dengan syarat sebagai berikut; 1) Modal harus diketahui jumlah dan jenisnya.

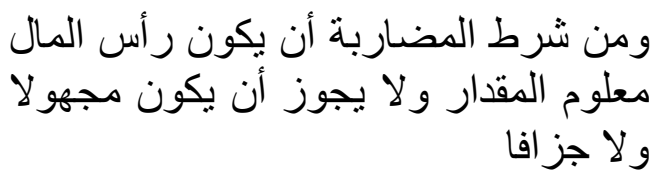

Artinya: Dan termasuk persyaratan mudharabah adalah modal harus diketahui jumlah nominalnya dan tidak diperbolehkan bila majhul (tidak diketahui) nominalnya atau juzaf

\footnotetext{
${ }^{19}$ Muhammad Bin Umar Nawawi Al Jawi, Nihayatuz Zain Fi Irsyadil Mubtadi'in (Beirut: Darul Kutub Al Ilmiyah, 2002), 249.

${ }^{20}$ Fatwa Dewan Syari'ah Nasional Nomor 07/Dsn-Mui/Iv/2000 tentang Pembiayaan Mudharabah (Qiradh) yang dipublikasikan oleh www.dsnmui.or.id diakses pada 15 Desember 2016.
}

(sesuatu yang dikira-kira tanpa ada timbangan atau takaran). ${ }^{21}$

$$
\text { الثرط الثاني: أن يكون معلوما }
$$

Artinya: Syarat yang kedua, (modal) harus diketahui. ${ }^{22}$

2) Modal harus berbentuk uang (alat bayar) baik dinar, dirham atau yang lain An Nawawi menjelaskan syarat modal yakni;

$$
\text { والإجماع الدراعم والدنانير المضروبة، ودليله }
$$

Artinya: Yakni dirham dan dinar yang dicetak, dan dalilnya adalah ijma (konsensus). ${ }^{23}$

3) Modal tidak dapat berbentuk piutang dan harus dibayarkan kepada mudharib (pengelola modal), baik secara bertahap maupun tidak, sesuai dengan kesepakatan dalam akad.

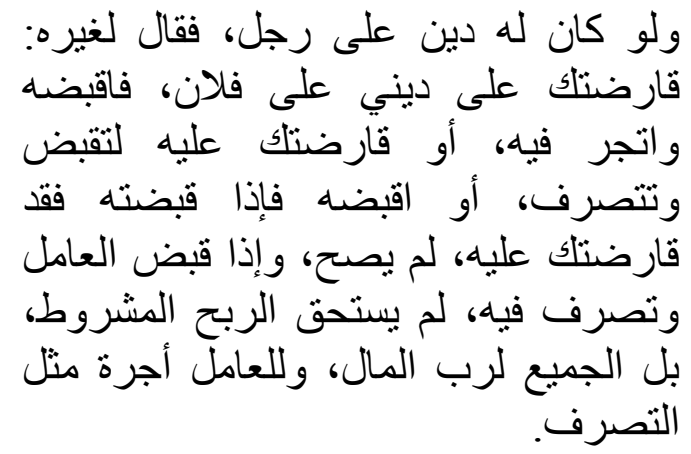

Artinya: Kalau seandainya dia punya piutang pada seseorang lalu berkata kepada pihak ketiga: 'Aku lakukan akad qiradh denganmu. Modalnya adalah piutangku pada si fulan. Ambil dan kelolalah untuk sebuah usaha' atau dia berkata 'Aku adakan akad qiradh denganmu. Ambil piutangku dan pakai sebagai modal usaha' atau dia berkata 'Ambil piutangku, jika

\footnotetext{
${ }^{21}$ Ibnu Qudamah, Al Mughni, jilid 7 (Riyadh: Dar 'Alamul Kutub, 1997), 183.

${ }^{22}$ Abu Zakaria An Nawawi, Raudhatut Thalibin Wa Umdatul Muftin, Jilid 5 (Beirut:Al Maktab Al Islami, 1991), 117

${ }^{23}$ Abu Zakaria An Nawawi, Raudhatut Thalibin Wa Umdatul Muftin, 117.
} 
sudah kamu pegang maka itu sebagai modal qiradh antara kita.' Ini semua tidak sah. Bila sang amil (pengelola) sudah mengambilnya dan mengelola sebuah usaha, maka dia (si A) tidak berhak mendapatkan laba yang dipersyaratkan. Semua harta milik pemodal (shahibul maal), sedangkan sang amil hanya mendapatkan upah sebagai pegawai. ${ }^{24}$

Keempat, keuntungan mudharabah adalah jumlah yang didapat sebagai kelebihan dari modal. Syarat keuntungan berikut ini harus dipenuhi; 1) Harus diperuntukkan bagi kedua pihak dan tidak boleh disyaratkan hanya untuk satu pihak.

$$
\begin{aligned}
& \text { الركن الخامس الربح وله شروط منها } \\
& \text { اختصاصه بالمالك و والعامل و واشتر اكهما } \\
& \text { فيه وتقدير نصيب كل منهما بجزئية }
\end{aligned}
$$

Artinya: Rukun mudharabah kelima adalah keuntungan. Rukun ini memiliki beberapa persyaratan di antaranya, keuntungan hanya milik pemodal dan pelaku usaha. Hendaknya mereka berdua samasama memilikinya, dan hendaknya bagian masing-masing dari mereka ditentukan dalam prosentase. ${ }^{25}$

2) Bagian keuntungan proporsional bagi setiap pihak harus diketahui dan dinyatakan pada waktu kontrak disepakati dan harus dalam bentuk prosentasi (nisbah) dari keuntungan sesuai kesepakatan. Perubahan nisbah harus berdasarkan kesepakatan. ${ }^{26}$

Dan 3) Penyedia dana menanggung semua kerugian akibat dari mudharabah, dan pengelola tidak boleh menanggung kerugian apapun kecuali diakibatkan dari

\footnotetext{
${ }^{24}$ Abu Zakaria An Nawawi, Raudhatut Thalibin Wa Umdatul Muftin, 117-118.

${ }^{25}$ Muhammad Bin Umar Nawawi Al Jawi, Nihayatuz Zain Fi Irsyadil Mubtadi'in (Beirut: Darul Kutub Al Ilmiyah, 2002), 250.

${ }^{26}$ Lihat Muhammad Bin Umar Nawawi Al Jawi, Nihayatuz Zain Fi Irsyadil Mubtadi'in 250.
}

kesalahan disengaja, kelalaian, atau pelanggaran kesepakatan. ${ }^{27}$

Dan kelima, kegiatan usaha oleh pengelola (mudharib), sebagai perimbangan modal yang disediakan oleh penyedia dana, ${ }^{28}$ harus memperhatikan hal-hal berikut; pertama, kegiatan usaha adalah hak eksklusif pengelola (mudharib), tanpa campur tangan penyedia dana, tetapi ia mempunyai hak untuk melakukan pengawasan. Kedua, penyedia dana tidak boleh mempersempit tindakan pengelola sedemikian rupa yang dapat menghalangi tercapainya tujuan mudharabah, yaitu keuntungan. Dan ketiga, pengelola tidak boleh menyalahi hukum Syari'ah Islam dalam tindakannya yang berhubungan dengan mudharabah. Sebagaimana ditegaskan di bawah ini:

$$
\begin{aligned}
& \text { فصل: وليس له أن يشتري خمرا ولا } \\
& \text { خنزيرا، سواء كانا مسلمين أو أو كان } \\
& \text { أحدهما مسلما والآخر ذميا، فإن فعل، } \\
& \text { فعليه الضمان. وبهذا قال الثـافعي. }
\end{aligned}
$$

Artinya: Tidak diperbolehkan bagi sang amil membeli khamr atau babi, baik keduanya (pemodal dan pengelola) muslim atau salah satunya muslim yang lainnya dzimmil. Bila dia lakukan maka wajib ganti rugi. Ini juga pendapatnya Asy-Syafi' 'i. ${ }^{29}$

\section{METODOLOGI PENELITIAN}

Jenis Penelitian yang digunakan ialah penelitian kualitatif yaitu penelitian yang bersifat deskriptif. jenis penelitian kualitatif adalah jenis penelitian yang temuantemuannya tidak diperoleh melalui prosedur statistik atau bentuk hitungan lainnya. ${ }^{30}$

\footnotetext{
${ }^{27}$ Lihat Ibnu Qudamah, Al Mughni, 162.

${ }^{28}$ Fatwa Dewan Syari'ah Nasional Nomor 07/Dsn-Mui/Iv/2000 tentang Pembiayaan Mudharabah (Qiradh) yang dipublikasikan oleh www.dsnmui.or.id. Diakses pada 15 Desember 2016.

${ }^{29}$ Ibnu Qudamah, Al Mughni, 158.

${ }^{30}$ Boedi Abdullah dan Beni Ahmad Saebani, Metode Penelitian Ekonomi Islam (Muamalah) (Bandung: Pustaka Setia, 2014), 49.
} 
Adapun sumber data yang digunakan dalam penelitian kali ini, yaitu pertama, sumber primer yaitu hasil-hasil penelitian atau tulisan-tulisan karya peneliti atau teoritisi yang orisinil, ${ }^{31}$ dalam hal ini sumber data primer yang digunakan adalah berbagai literatur yang khusus/berkaitan membahas tentang status ganda di Perbankan Syariah, literatur dapat berupa buku, jurnal, majalah, dan sebagainya.

Dan kedua, sumber data sekunder yang menjadi pendukung adalah literatur pendukung lain yang masih ada hubungannya dengan analisi yang dilakukan, namun tidak secara khusus membahas tentang status ganda perbankan syariah.

Teknik pengumpulan data yang dilakukan dalam penelitian ini adalah studi kepustakaan. Studi kepustakaan atau penelitian kepustakaan yaitu teknik pengumpulan data dengan melakukan penelitian terhadap berbagai literatur dan dilakukan untuk mencari konsep yang ada relevansinya dengan topik pembahasan melalui pengkajian buku-buku, jurnal, majalah serta pendapat-pendapat para ahli secara tidak langsung. Dalam hal ini literatur yang digunakan merujuk kepada fikih muamalah Islam, praktek dan peraturan perbankan syariah. Semua literatur yang ada akan dibandingkan satu sama lain dengan pendapat yang sesuai dengan hukum ekonomi syariah pada literatur fikih muamalah Islam, hal tersebut dilakukan dengan analisis yang mendalam.

Kemudian, analisis data adalah proses mengorganisasikan dan mengurutkan data kedalam pola, kategori dan satuan uraian dasar sehingga dapat ditemukan tema dan dapat dirumuskan hipotesis kerja seperti yang disarankan oleh data. ${ }^{32}$

Teknik analisa data yang digunakan oleh peneliti dalam melakukan analisis data

\footnotetext{
${ }^{31}$ Ibnu Hadjar, Dasar-dasar Metodologi Penelitian Kuantitatif dalam Pendidikan (Jakarta: Raja Grafindo Persada, 1996), 83.

${ }^{32}$ Ley J. Moeloeng, Metodologi Penelitian Kualitatif (Bandung: Remadja Karya CV, 1986), 281.
}

adalah dengan menggunakan teknik analisa data kualitatif yaitu dengan cara;

Pertama, menelaah seluruh data yang telah terkumpul, dalam hal ini dilakukan dengan cara penelaahan data primer terlebih dahulu, yakni data yang memang berkaitan erat dengan tema analisis yang dilakukan, dalam proses tersebut, peneliti dapat menganalisa dan mengkritisi penelitian terdahulu dan membandingkannya satu sama lain, Data primer juga sangat dibutuhkan dalam proses analisis permasalahan karena data tersebut dapat memperjelas, memperkuat dan menambah analisis yang dilakukan agar memiliki argumen yang kuat. Setelah itu barulah menelaah data sekunder. Dalam menelaah data dilakukan secara deskriptif dan reflektif. Deskriptif yaitu menerangkan gambaran umum mengenai objek yang sedang diteliti, sedangkan Reflektif yaitu menerangkan objek penelitian yang kita teliti secara lebih mendalam dengan menambahkan intepretasi dan persepsi terhadap obyek yang diteliti/sedang dikaji.

Kedua, melakukan reduksi data, yaitu menyeleksi data dengan memilih yang penting saja sehingga rangkuman inti dari penelitian tersebut tetap berada didalamnya dan hasil penelitian yang diteliti akan lebih fokus.

Ketiga, kategorisasi, yaitu mengelompokkan data sesuai kategori dengan menyesuaikan obyek kajian yang akan dianalisa.

Dan keempat, mamaknai data yang sudah didapat yaitu semakin dimaknai dengan pertimbangan-pertimbangan apakah sudah sesuai dengan teori yang dipakai atau belum. 


\section{TINJAUAN PERAN PERBANKAN SYARIAH SEBAGAI LEMBAGA INTERMEDIASI KEUANGAN TERHADAP KEABSAHAN AKAD MUDHARABAH}

Pertama, status perbankan yang tidak jelas. Perbankan syariah berstatus sebagai sebagai pengelola usaha (mudharib) ketika berhubungan dengan nasabah pemodal (shahibul maal), kemudian dalam waktu sekejap berubah status menjadi pemodal (shahibul maal) untuk mencari pelaku usaha (mudharib) yang sesungguhnya.

Kedua, bank tidak memiliki usaha riil. Undang-undang Perbankan Syariah tidak mengisyaratkan bank syariah untuk memiliki usaha riil dan terjun langsung dalam dunia usaha, maka dengan hal ini sesuatu yang musykil bagi bank syariah dalam menjalankan akad mudharabah pada usaha riil yang hakekatnya memang tidak pernah dimiliki. Dengan demikian, pada setiap unit usaha yang dikelola, peran perbankan hanya sebagai penyalur dana nasabah

\section{ANALISIS STATUS GANDA PERBANKAN SYARIAH DALAM AKAD MUDHARABAH MENURUT HUKUM EKONOMI SYARIAH}

Menurut para ulama bila perbankan memerankan peranan ganda atas seizin pemodal, maka bank tidak berhak mendapatkan bagian dari keuntungan, karena statusnya hanyalah sebagai perantara (calo/wakil),

Jika bank bertindak sebagai shahibul mal, maka hal tersebut menunjukan bahwa modal yang diberikan nasabah pemodal (shahibul maal) berpindah kepemilikan kepada bank, dan akad tersebut adalah akad piutang. Selain itu, ketika nasabah (investor) menyetorkan modalnya dalam akad mudharabah kepada pihak bank seharusnya konsekuensi dari akad tersebut adalah si nasabah memiliki bagian atas kepemilikan lembaga keuangan bank tersebut tapi pada kenyataannya tidak demikian, ini menjelaskan bahwa akad yang terjadi adalah utang piutang.

\section{DAMPAK STATUS GANDA TERHADAP METODE BAGI HASIL PERBANKAN SYARIAH}

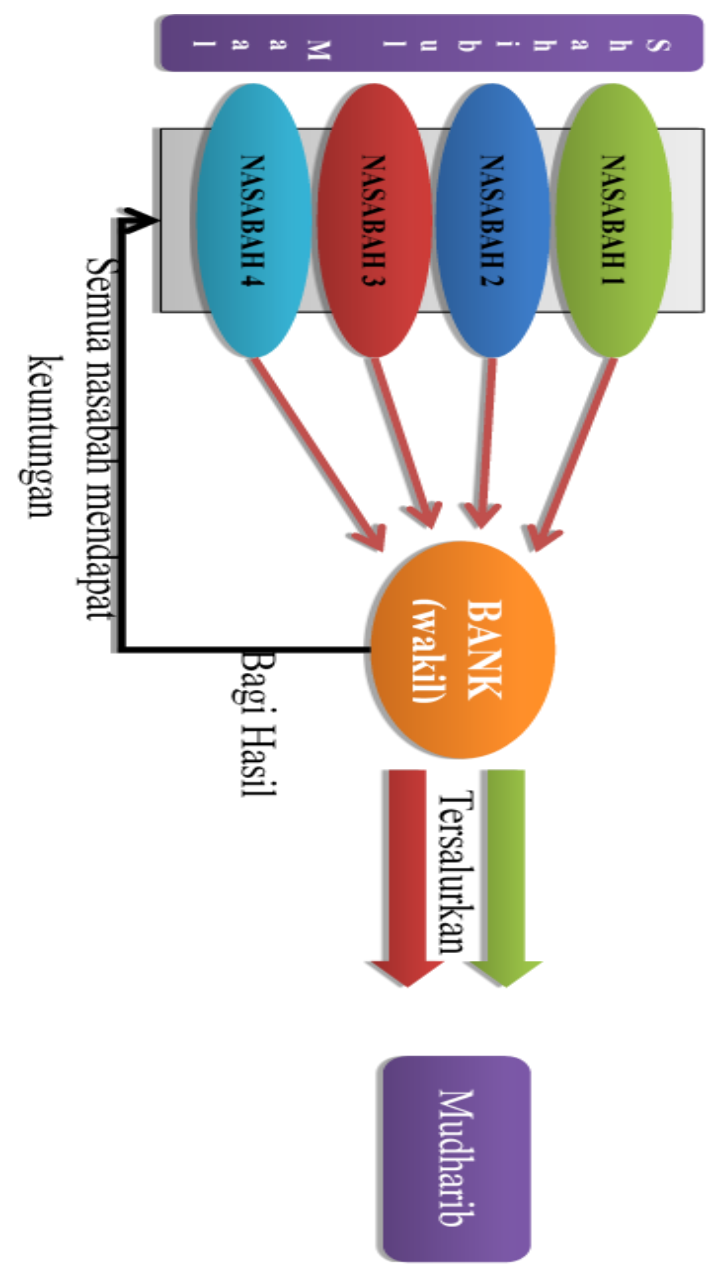

Di Perbankan syariah, seluruh nasabah mendapatkan bagian dari hasil/keuntungan, padahal status bank hanya sebagai wakil bukan pelaku usaha, dalam metode mudharabah yang Islami, yang menjadi pertimbangan dalam membagikan keuntungan kepada nasabah adalah keuntungan yang diperoleh dari masingmasing dana nasabah. Sehingga nasabah yang dananya belum disalurkan, tidak berhak untuk mendapatkan bagian dari hasil.

Selain itu, dalam perbankan syariah, salah satu perhitungan bagi hasilnya adalah rata-rata total modal (dana) nasabah. Adapun dalam akad mudharabah, maka yang dihitung adalah keuntungan atau hasilnya, oleh karenanya akad ini dinamakan bagi hasil. 


\section{KESIMPULAN}

Berdasarkan urian di atas dapat diambil 2 (dua) kesimpulan, yaitu pertama, perbankan syariah sebagai lembaga intermediasi keuangan dalam akad Mudharabah menghasilkan dua tinjauan, Pertama, status perbankan yang tidak jelas (status ganda). Kedua, bank tidak memiliki usaha riil. Undang-undang Perbankan Syariah tidak mengisyaratkan bank syariah untuk memiliki usaha riil dan terjun langsung dalam dunia usaha, maka dengan hal ini sesuatu yang musykil bagi bank syariah dalam menjalankan akad mudharabah pada

usaha riil yang hakekatnya memang tidak pernah dimiliki.

Dan kedua, Menurut para ulama bila perbankan memerankan peranan ganda atas seizin pemodal, maka bank tidak berhak mendapatkan bagian dari keuntungan, karena statusnya hanyalah sebagai perantara (wakil), Jika bank bertindak sebagai shahibul maal, maka hal tersebut menunjukan bahwa modal yang diberikan nasabah pemodal (shahibul maal) berpindah kepemilikan kepada bank, dan akad tersebut adalah akad piutang.

\section{DAFTAR PUSTAKA}

Abdullah, Boedi dan Beni Ahmad Saebani. Metode Penelitian Ekonomi Islam (Muamalah). Bandung: Pustaka Setia, 2014.

Al-Hanafy, Al-Kasany. Badaa'i Ash Shanaa'i Fi Tartib Asy Syara'i, Jilid 6. Beirut: Darul Kutub Al Ilmiyah, 1986.

Al-Jawi, Muhammad Bin Umar Nawawi. Nihayatuz Zain Fi Irsyadil Mubtadi'in. Beirut: Darul Kutub Al Ilmiyah, 2002.

Al-Nawawi, Abu Zakaria. Raudhatut Thalibin Wa Umdatul Muftin, Jilid 5. Beirut: Al Maktab Al Islami, 1991.

Hadjar, Ibnu. Dasar-dasar Metodologi Penelitian Kuantitatif dalam Pendidikan. Jakarta: Raja Grafindo Persada, 1996.

Harahap, Sofyan Syafri, eds. Akutansi Perbankan Syariah. Jakarta: LPFE Usakti, 2005.
Hardini, Isriani dan Muh. Giharto. Kamus

Perbankan Syariah: Dilengkapi

Penjelasan Singkat dan

Perbandingan dengan Bank

Konvensional. Bandung: Marja, 2007.

Ibnu Qudamah, Al Mughni, jilid 7. Riyadh: Dar 'Alamul Kutub, 1997.

Moeloeng, Ley J. Metodologi Penelitian Kualitatif. Bandung: Remadja Karya CV, 1986.

Prides dan Tim Manajemen. Kompilasi Perundang-undangan tentang Ekonomi Syariah. Jakarta: Gaung Persada Press, 2008.

Soemitra, Andri. Bank dan Lembaga Keuangan Syariah. Jakarta: Kencana, 2009.

Susilo, Y. Sri eds. Bank dan Lembaga Keuangan Lain. Jakarta: Salemba Empat, 2000.

Sutedi, Adrian. Perbankan Syariah Tinjauan dan Beberapa Segi Hukum. Bogor: Ghalia Indonesia, 2009.

Syafei, Rachmat. Fiqih Muamalah. Bandung: Pustaka Setia, 2001.

Tarmizi, Erwandi. Harta Haram Muamalat Kontemporer. Bogor: PT. Berkat Mulia Insani, 2014.

Undang-Undang Nomor 21 tahun 2008 tentang Perbankan Syariah.

www.dsnmui.or.id.

www.sjdih.depkeu.go.id. 